\title{
TINJAUAN FIKIH ISLAM TERHADAP UNDANG-UNDANG NOMOR 1 TAHUN 1974 TENTANG TALAK
}

\section{ISLAMIC JURISPRUDENCE VIEW ON LAW NUMBER 1 YEAR 1974 CONCERNING TALAK}

\section{Kasman Bakry}

Sekolah Tinggi Ilmu Islam dan Bahasa Arab (STIBA) Makassar Email: kasmanbakry@stiba.ac.id

\section{Sirajuddin}

Sekolah Tinggi Ilmu Islam dan Bahasa Arab (STIBA) Makassar Email: sirajuddin.syarif@stiba.ac.id

\section{Musriwan}

Sekolah Tinggi Ilmu Islam dan Bahasa Arab (STIBA) Makassar

Email: musriwan@stiba.ac.id

\section{Ahmad Arfah Mansyah}

Sekolah Tinggi Ilmu Islam dan Bahasa Arab (STIBA) Makassar Email: ahmad.am@gmail.com

\begin{tabular}{ll}
\hline Keywords : & \multicolumn{1}{c}{ ABSTRACT } \\
\cline { 2 - 3 } Divorce, Divorce Registration, & This study aimed to determine the review of Islamic jurisprudence on \\
Law No. 1 of 1974 concerning the stipulation of rules requiring divorce \\
before the Religious Courts. The research method was descriptive \\
qualitative research with library research techniques, which focuses on \\
the study of manuscripts and texts, and uses normative and philosophical \\
juridical approaches. The results of the study showed that even in \\
Islamic jurisprudence, divorce can occur and be considered valid, \\
anytime and anywhere, if the husband who handed down the divorce is \\
mature, reasonable, and not under pressure or coercion. However, Law \\
Number 1 of 1974 requires that a divorce be valid, and divorce must be \\
filed and carried out in front of a religious court session. This \\
requirement does not conflict with Islamic jurisprudence, even scholars \\
agree on the witness of divorce. \\
\hline $\begin{array}{l}\text { ABSTRAK } \\
\text { Talak, Pencatatan } \\
\text { Talak,Pengadilan Agama }\end{array}$ \\
$\begin{array}{l}\text { Penelitian ini bertujuan untuk mengetahui tinjauan fikih Islam terhadap } \\
\text { Undang-Undang Nomor } 1 \text { tahun } 1974 \text { tentang penetapan aturan yang } \\
\text { mewajibkan talak di depan pengadilan Agama. Metode penelitian yang } \\
\text { digunakan adalah penelitian deskriptif kualitatif dengan teknik kajian } \\
\text { kepustakaan (library research), yang terfokus pada studi naskah dan } \\
\text { teks, serta menggunakan metode pendekatan yuridis normatif dan } \\
\text { filosofis. Hasil penelitian menunjukkan bahwa meskipun dalam fikih } \\
\text { Islam, talak bisa saja terjadi dan dianggap sah, kapanpun dan di } \\
\text { manapun, jika suami yang menjatuhkan talak tersebut telah balig, } \\
\text { berakal dan tidak berada dalam tekanan atau paksaan. Namun, Undang- } \\
\text { Undang Nomor } 1 \text { Tahun } 1974 \text { mensyaratkan untuk sahnya suatu talak, } \\
\text { dan talak mesti diajukan dan dilakukan di depan sidang pengadilan }\end{array}$ \\
\hline
\end{tabular}


Diterima: 13 Agustus 2021; Direvisi: 18 Agustus 2021; Disetujui: 18 Agustus 2021; Tersedia online: 20 Agustus 2021

How to cite: Kasman Bakry, Sirajuddin, Musriwan, Ahmad Arfah Mansyah., "Tinjauan Fikih Islam Terhadap Undang-Undang Nomor 1 Tahun 1974 Tentang Talak", BUSTANUL FUQAHA: Jurnal Bidang Hukum Islam 2, No. 2 (2021): 348-362. doi: 10.36701/bustanul.v2i2. 373.

\section{PENDAHULUAN}

Sebagai negara muslim terbesar di dunia ${ }^{1}$, Indonesia berusaha memberlakukan hukum-hukum Allah swt. dalam penerapan hukum di Indonesia. Hukum-hukum Islam di Indonesia ada yang dibahas secara umum dalam perundang-undangan negara Indonesia dan ada pula yang dibahas lebih detail. Hukum Islam yang dibahas secara umum dalam undang-undang Indonesia seperti tata cara beribadah kepada Allah swt., seperti salat, wudhu, puasa Ramadan dan ibadah lainnya baik yang bersifat wajib atau yang sunah. Sebagaimana dalam Undang-Undang Dasar hasil Amandemen pasal 29 ayat (2) yang berbunyi, "Negara menjamin kemerdekaan tiap-tiap penduduk untuk memeluk agamanya masing-masing dan untuk beribadat menurut agamanya dan kepercayaannya itu." " Dalam pasal ini, Negara Indonesia memberikan kewenangan kepada warganya dalam memeluk agama dan beribadah sesuai dengan ajaran agamanya yang dianggap benar.

Hukum Islam yang dibahas secara detail dalam hukum Indonesia di antaranya adalah hukum perkawinan, hukum kewarisan, dan hukum perwakafan dalam Kompilasi Hukum Islam (KHI). Menurut Hikmatullah, dengan adanya KHI di Indonesia, maka pluralisme Keputusan Peradilan Agama dapat diminimalisir, karena kitab yang dijadikan rujukan hakim Peradilan Agama adalah sama ${ }^{3}$. Selain itu, pengelolaan zakat, tata cara penyelenggaraan haji, dan peradilan agama juga diatur dalam perundang-undangan di Indonesia. Namun, dalam penerapan hukum Islam di Indonesia ditengarai terdapat beberapa masalah yang tampak berbeda dengan hukum fikih Islam, terutama yang dibahas dalam Kompilasi Hukum Islam. Sebagaimana dalam Kompilasi Hukum Islam Bab I: Hukum Perkawinan Bab XVI Pasal (113) berbunyi, "Perceraian hanya dapat dilakukan di depan sidang Pengadilan Agama setelah Pengadilan Agama tersebut berusaha dan tidak berhasil mendamaikan kedua belah pihak." Dalam Kompilasi Hukum Islam, perceraian atau talak hanya dapat dilakukan dan dianggap sah di depan Pengadilan Agama, sebagaimana bunyi Undang-Undang Perkawinan Nomor 1 Tahun 1974. Berbeda halnya dengan hukum fikih Islam, talak dapat dijatuhkan dan dianggap sah ketika terpenuhi syarat-syaratnya.

Berdasarkan pokok persoalan di atas, maka penulis berupaya menemukan titik temu antara UU No. 1/1974 dengan tinjauan dalam fikih Islam. Dalam pengkajiannya, penulis

\footnotetext{
${ }^{1}$ Databoks, "Indonesia, Negara dengan Penduduk Muslim Terbesar Dunia”, Situs Resmi Databoks. http://databoks.katadta.co.id/datapublish/2019/09/25/indonesia-negara-dengan-pendudukterbesar-dunia (22 Desember 2019).

${ }^{2}$ Redaksi Visimedia, UUD 1945 (Cet. III; Jakarta: Visimedia, 2007), h. 11.

${ }^{3}$ Hikmatullah, Hikmatullah. "Selayang Pandang Sejarah Penyusunan Kompilasi Hukum Islam Di Indonesia." Ajudikasi: Jurnal Ilmu Hukum 1.2 (2017).
} 


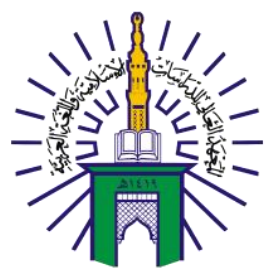

\section{BUSTANUL FUQAHA: \\ JURNAL BIDANG HUKUM ISLAM \\ Vol. 2 No. 2 (2021): Hal. 348-362 \\ EISSN: 2723-6021 \\ Website: https://journal.stiba.ac.id}

\section{BUSTANUL FUQAHA}

Jurnal Bidang Hukum Islam

menetapkan tujuan yaitu untuk mengetahui bagaimana pandangan fikih Islam terhadap aturan yang mewajibkan talak di depan pengadilan. Adpun metode penelitian yang digunakan dalam penelitian ini adalah metode deskriptif kualitatif (non-statistik) dengan teknik kajian kepustakaan (library research) yang terfokus pada studi naskah dan teks, serta menggunakan metode pendekatan yuridis normatif dan filosofis.

Dari pengamatan penulis sejauh ini, telah didapati beberapa penelitian terdahulu terkait kewajiban talak di pengadilan agama, di antaranya;

1. Penelitian yang berjudul "Keabsahan Talak Dalam Perspektif Hukum Positif Dan Fikih Munakahat: Konflik Norma." Hasil dari penelitian ini, bahwa cerai tanpa putusan pengadilan itu tidak sah, sesuai dengan pasal 39 ayat (1) Undang-Undang no. 1 tahun 1974 tentang perkawinan ${ }^{4}$.

2. Penelitian yang berjudul "Analisis Terhadap Perceraian Melalui SMS Pada Kasus Aceng Fikri (Bupati Garut) Menurut Undang-Undang Nomor 1 Tahun 1974 Tentang Perkawinan." Hasil penelitian mengemukakan bahwa talak melalui pesan singkat SMS dalam aspek hukumnya jatuh karena memiliki kesamaan dengan surat asalkan memenuhi syarat-syarat pengirimnya adalah sang suami, harus punya niat/kehendak untuk bercerai, kalimat yang diucapkan tidak boleh salah, dan sang istri harus menerima pesan tersebut. Akan tetapi, talak yang dilakukan dengan menggunakan alat komunikasi modern adalah kaedah perceraian yang tidak menepati adab perceraian yang digariskan oleh syara. Pada kasus Aceng Fikri perceraian melalui pesan singkat SMS hukumnya sah secara agama, tetapi belum sah secara hukum negara karena belum dilakukan di depan sidang pengadilan agama ${ }^{5}$.

Dengan demikian, berdasarkan kajian-kajian di atas tampak belum mengkaji sisi tinjauan fikih Islam terhadap UU No. 1/1974 tentang talak yang mempersyaratkan bahwa talak dianggap sah jika dilakukan di pengadilan agama. Untuk itu, kajian ini berupaya menemukan titik temu antara tinjauan fikih Islam UU No. 1/1974 tentang talak. Hal ini tidak lain bertujuan untuk memperkaya khasanah kajian Islamic studies (studi keislaman), alih-alih diharapkan dapat bermanfaat bagi umat dan bangsa.

\section{PEMBAHASAN}

\section{Talak dalam Fikih Munakahat}

Para fukaha berpendapat, bahwa talak merupakan syariat yang memiliki lima hukum atau biasa disebut dengan istilah al-Ahkäm al-Taklïfiyyah al-Khamsah ${ }^{6}$, tergantung dengan situasi dan kondisi yang mempengaruhinya. Talak hukumnya haram ketika menceraikan istri yang sedang haid, atau menceraikan istri yang sedang suci (dari haid)

4 Hasyim Fahmi."Keabsahan Talak dalam Perspektif Hukum Positif dan Fiqih Munakahat (Konflik Norma)". Skripsi. Malang: Fak. Syariah Universitas Islam Negeri Maulana Malik Ibrahim Malang, 2017.

5 Aila Laila. Analisis Terhadap Perceraian Melalui SMS Pada Kasus Aceng Fikri (Bupati Garut) Menurut Undang-Undang Nomor 1 Tahun 1974 Tentang Perkawinan/oleh Aila Laila. Diss. UNIVERSITAS TARUMANEGARA, 2013.

6 'Abdul Karim ibn 'Ali ibn Muhammad al-Namlah, Al-Mazhab Fi 'Ilmi Ushul al-Fiqh alMuqaran, Jilid 1, h. 43. 


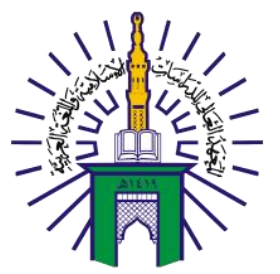

\section{BUSTANUL FUQAHA: \\ JURNAL BIDANG HUKUM ISLAM \\ Vol. 2 No. 2 (2021): Hal. 348-362 \\ EISSN: 2723-6021 \\ Website: https://journal.stiba.ac.id}

namun sebelumnya telah digauli dan talak seperti ini disebut dengan talak bid 'i ${ }^{6}$. Talak hukumnya makruh, ketika tidak dalam rangka menghindari sebuah mudarat dalam rumah. Bahkan hukum ini bisa saja menjadi haram dalam sebagian kondisi. Hukum ini berdalilkan hadis yang diriwayatkan oleh sahabat yang mulia Jabir ra.,

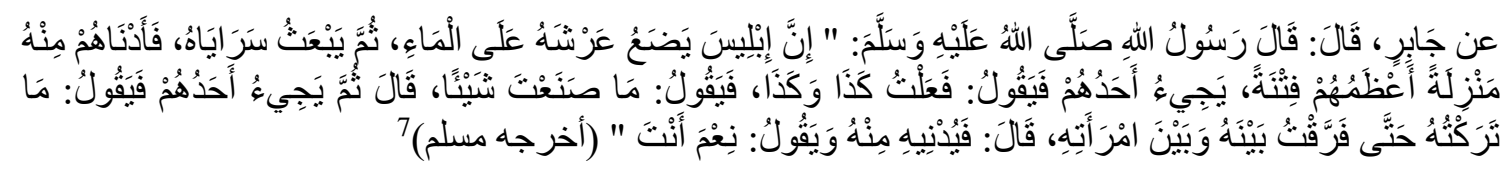

Artinya:

Dari Jābir, dia berkata, Rasulullah saw. bersabda: "Sesungguhnya iblis meletakkan singgasananya di atas air, lalu mengirim bala tentaranya. Yang paling rendah (dari bala tentaranya) bagi iblis adalah yang paling besar godaanya. Salah satu di antara mereka datang lalu berkata: 'aku telah melakukan ini dan itu.' Kemudian iblis berkata: 'kau tidak melakukan apa pun.' Lalu yang lain datang lalu berkata: 'Aku tidak meninggalkannya sampai aku memisahkannya dengan istrinya.' Nabi saw. bersabda: 'Iblis mendekatinya lalu berkata: 'Bagus kamu." (H.R. Muslim).

Juga hadis 'Amru ibn Dīnār ra..

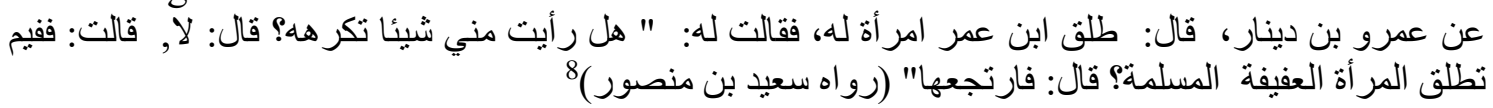

Artinya:

Dari "Amru ibn Dīnār ra., dia berkata: "Ibn Umar menceraikan istrinya," maka istrinya berkata: "Apakah kau melihat sesuatu yang kau tidak suka dariku?" Dia menjawab: "Tidak." Lalu istrinya berkata: "Lalu kenapa kau menceraikan perempuan terhormat dan muslimah?" Dia ('Amru) berkata: "Maka Ibn Umar merujuknya." (H.R. Sa'īd ibn Manșūr).

Talak hukumnya mubah, ketika akhlak dan pergaulan istri buruk, dan dan dikhawatirkan munculnya mudarat ketika tetap bersamanya, dan tidak ada hal yang baik yang didapatkan darinya. Talak hukumnya mustahab (dianjurkan), ketika istri lalai dari menunaikan hak-hak Allah swt. atasnya seperti salat dan sebagainya, dan tidak mungkin untuk memaksanya (dalam menunaikan hak-hak Allah swt.), atau istri menjadi perempuan yang tidak berbudi luhur, tidak baik dalam melayani suami, dan dia tidak memperbaiki kekurangan agamanya, maka tidak mengapa untuk mengekangnya dan mempersempitnya dalam keadaan ini agar dia mau memperbaikinya, sebagaimana firman Allah swt. dalam Qs. al-Nisā/4: 19,

\footnotetext{
${ }^{6}$ Rahmat, Rahmat, and Sri Indriani. "Hukum Idah Perceraian bagi Wanita Hamil Akibat Perbuatan Zina." BUSTANUL FUQAHA: Jurnal Bidang Hukum Islam 1.4 (2020), h. 598.

${ }^{7}$ Muslim ibn al-Hajjāj al-Qusyairī al-Naisābūrī, Șaḥịh Muslim, Jilid 4 (t.Cet.; Beirut: Dār Ihyā̄ alTurās al-'Arabī, 1374 H/ 1954 M), h. 2167.

${ }^{8}$ Sa'īd ibn Manșūr al-Khurasānī al-Jauzajān̄̄, Sunan Sa '̄̄d ibn Manșūr, Jilid 1 (Cet. I; India: al-Dār al-Salafiyyah, 1403 H/1982 M), h. 307.
} 
Terjemahnya:

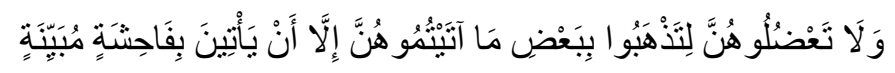

Dan janganlah kamu menyusahkan mereka karena hendak mengambil kembali sebagian dari apa yang telah kamu berikan kepada mereka, kecuali apabila mereka melakukan perbuatan keji yang nyata ${ }^{9}$.

Namun, talak dalam keadaan ini hukumnya bisa berubah menjadi wajib. Talak hukumnya wajib, seperti pada suami yang $m \bar{u} l \bar{l}$ (dia bersumpah tidak akan berhubungan dengan istrinya sampai pada waktu yang ditentukan), jika dia tidak menginginkan rujuk setelah habis waktu menunggu pada waktu yang telah ditentukan. Atau talak di antara suami dan istri yang berselisih sedang tidak ada jalan bagi keduanya untuk damai, dan keduanya memilih untuk talak atau cerai, maka talak hukumnya wajib menurut pendapat jumhur ulama. Adapun syarat sahnya talak dapat dibagi menjadi tiga kelompok; syarat yang berkaitan dengan penjatuh talak, syarat yang berkaitan dengan yang tertalak dan syarat yang berkaitan dengan sigah talak.

Adapun syarat-syarat yang berkaitan dengan penjatuh talak adalah:

\section{1) Berstatus sebagai suami}

Dengan kata lain, antara dia dan perempuan yang ingin dicerainya telah terikat akad nikah yang sah. Laki-laki tidak memiliki hak cerai kecuali jika dia berstatus sebagai suami yang sah. Ini sejalan dengan firman Allah swt. dalam Qs al-Aḥzāb/33: 49, di mana Allah menyebutkan perceraian setelah (terjadinya) pernikahan ${ }^{10}$,

Terjemahnya:

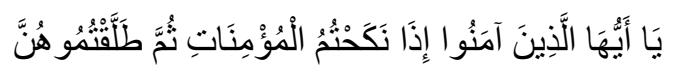

Wahai orang-orang yang beriman, apabila kamu menikahi perempuan-perempuan yang beriman, kemudian kamu ceraikan mereka ${ }^{11}$.

\section{2) Balig}

Jumhur ulama berpendapat bahwa talak tidak bisa dijatuhkan oleh anak kecil, baik sudah mumayiz atau belum, sebab talak adalah urusan yang sangat urgen dan tidak bisa diserahkan kepada anak kecil, begitu juga oleh walinya. Pendapat ini didasarkan pada hadis riwayat Aisyah ra., bahwa Rasulullah saw. bersabda:

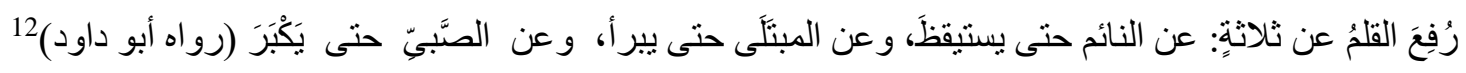

\footnotetext{
${ }^{9}$ Kementerian Agama Republik Indonesia, Al-Qur'an dan Terjemahnya, h. 80.

${ }^{10}$ Abū Mālik Kamāl ibn al-Sayyid Sālim, Saḥịh Fiqh al-Sunnah Wa Adillatuhu Wa Taudīh Maz̄āhib al-Aimmah, Jilid 3, h. 236.

${ }^{11}$ Kementerian Agama Republik Indonesia, Al-Qur'an dan Terjemahnya, h. 424.

${ }^{12}$ Abū Dāwud Sulaimān ibn al-Asy’aṡ ibn Ishạā al-Azdī al-Sijistān̄̄, Sunan Abī Dāwud, Jilid 6, h. 452.
} 


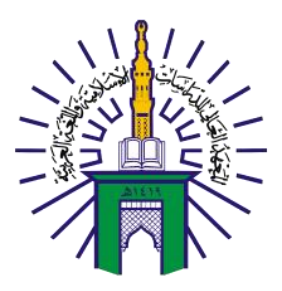

\section{BUSTANUL FUQAHA: \\ JURNAL BIDANG HUKUM ISLAM \\ Vol. 2 No. 2 (2021): Hal. 348-362 \\ EISSN: 2723-6021 \\ Website: https://journal.stiba.ac.id}

Artinya:

Tidak dicatat (amalan) dari tiga orang (ketentuan hukum tidak berlaku bagi tiga orang); orang tidur sampai dia terjaga, orang gila sampai dia sembuh, dan anak kecil sampai dia dewasa. (H.R. Abū Dāwud).

Sedangkan mazhab Hambali berpendapat, jika anak kecil sudah mumayiz, mengerti apa itu cerai, dan memahami konsekuensinya bahwa istrinya berstatus talak bain dan haram baginya, maka talaknya sah. Pendapat ini didasarkan pada hadis marfu' yang diriwayatkan oleh sahabat yang mulia 'Ali ra ${ }^{13}$.

Artinya:

$$
\text { كل طلاق جائز ، إلا طلاق المعتوه المغلوب على عقله (رو اه سعيد بن منصور ) }
$$

Setiap talak hukumnya boleh, kecuali talak orang idiot yang sangat bodoh. (H.R. Sa’’̄d ibn Manșūr).

Pendapat ini juga dipilih oleh Ibn Taimiyah, sebab dia menyatakan: "Akan tetapi ucapan anak kecil yang sudah mumayiz dan orang gila berkala memiliki implikasi hukum (mu'tabar) ketika ia bisa membedakannya. ${ }^{15 "}$

\section{3) Berakal}

Kata talak dari orang gila dan orang idiot tidak sah, karena orang gila tidak memiliki kapasitas mengambil keputusan, dan orang idiot kekurangan kapasitas mengambil keputusan. Ketentuan ini merujuk pada hadis Aisyah ra. yang telah dikemukakan sebelumnya. Ketentuan ini berlaku bagi orang gila permanen, sedangkan bagi orang gila berkala (kadang sembuh dan kadang kambuh), maka talak yang diucapkannya pada waktu gila tidak berlaku. Sedangkan talak yang diucapkannya pada waktu sembuh (sadar) berlaku atau sah karena kesempurnaan kapabilitasnya ${ }^{16}$.

\section{4) Menjatuhkan talak atas kemauan sendiri dan tidak berada di bawah tekanan (paksaan)}

Suami yang berada di bawah tekanan, maka talaknya tidak sah, karena Allah swt. mengangkat hukum dari orang yang melakukan sesuatu karena terpaksa. Hal itu karena talak merupakan tindakan yang memiliki pengaruh yang besar dan hasilnya pun langsung dirasakan dalam kehidupan suami-istri. Oleh karena itu, suami yang menjatuhkan talak kepada istrinya harus memenuhi syarat-syarat yang berlaku dengan kemauan dan tanpa paksaan agar semua tindakannya sah dan benar ${ }^{17}$.

Adapun syarat-syarat yang berkaitan dengan yang tertalak sebagai berikut;

\footnotetext{
${ }^{13}$ Abū Mālik Kamāl ibn al-Sayyid Sālim, Saḥịh Fiqh al-Sunnah Wa Adillatuhu Wa Tauḍ̄h Mazāhib al-Aimmah, Jilid 3, h. 236-237.

${ }^{14}$ Sa'̄̄d ibn Manșūr al-Khurasānī al-Jauzajān̄̄, Sunan Sa '̄̄d ibn Manșūr, Jilid 1, h. 310.

${ }^{15}$ Aḥmad ibn 'Abdul Halīm ibn Taimiyah, Majmū' al-Fatāwā, Jilid 33 (t. Cet.: Madinah; Mujamma’ al-Malik Fahd Li Ṭabā’ah al-Muṣhaf al-Syarīf, 1465 H/2004 M), h. 108.

${ }^{16}$ Abū Mālik Kamāl ibn al-Sayyid Sālim, Șaḥ̄ḥ Fiqh al-Sunnah Wa Adillatuhu Wa Tauḍ̄ḥ Mazāhib al-Aimmah, Jilid 3, h. 237.

${ }^{17}$ Sayyid Sābiq, Fiqh al-Sunnah, Jilid 2, h. 247.
} 
a) Istri yang sah dan masih berada dalam kekuasaan suami

Ulama sepakat bahwa talak jatuh pada perempuan yang menjalin tali pernikahan yang sah dengan pentalak, atau tengah menjalani masa idah setelah ditalak raj'i (talak yang masih bisa dirujuk), dan tidak jatuh pada perempuan ajnabiyyah (bukan mahramnya) atau perempuan yang belum halal baginya walau akan dinikahinya ${ }^{18}$. Adapun jika dia sedang menjalani masa idah talak bain ${ }^{19}$ atau fasakh, maka jumhur ulama menyatakan talak terhadapnya tidak berlaku lagi mengingat sudah berakhirnya pernikahan karena talak bain dan atau karena fasakh. Adapun jika istri ditalak sebelum melakukan hubungan intim, maka tidak ada masa idah baginya, berdasarkan firman Allah swt. dalam Qs. alAḥzāb/33:49,

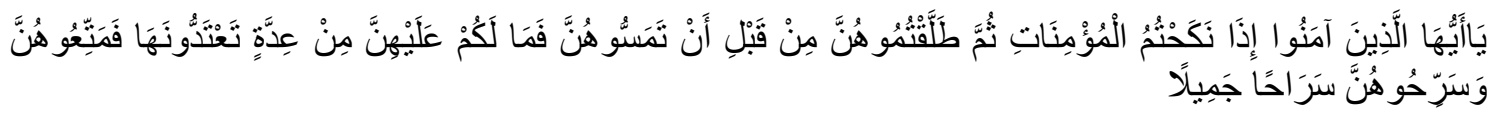

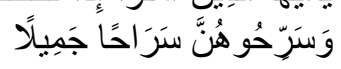

Terjemahnya:

Wahai orang-orang beriman! Apabila kamu menikahi perempuan-perempuan mukminat, kemudian kamu menceraikannya mereka sebelum kamu mencampurinya (berhubungan intim), maka tidak ada masa idah atas mereka yang perlu kamu perhitungkan. Namun berikanlah mereka mutah dan lepaskanlah mereka itu dengan cara yang sebaik-baiknya ${ }^{20}$.

Talak dalam kondisi ini termasuk talak bain, sehingga menurut kalangan mazhab Hanafi dan Syafi'i tidak bisa diikuti dengan talak lain. Jika seorang suami mengatakan kepada istrinya yang belum disanggamai (belum berhubungan intim), "Kamu tertalak! Kamu tertalak! Kamu tertalak!" (tiga kali talak), maka yang jatuh hanya satu, sebab dengan talak satu saja dia sudah tertalak bain dari suaminya dan menjadi perempuan ajnabiyyah (bukan mahram) baginya, sehingga praktis tidak bisa ditalak lagi ${ }^{21}$.

b) Suami harus menentukan istri mana yang akan ditalaknya, baik dengan isyarat, sifat, atau niat, atau dengan ketiga-tiganya sekaligus ${ }^{22}$.

Misalnya, seorang suami mengatakan kepada istrinya yang bernama Zainab, sembari memberikan isyarat kepadanya, dan dengan niat menalaknya, "Hai Zainab, kamu tertalak!", maka ulama sepakat bahwa telah jatuh talaknya. Begitu pula jika dia menunjuk

\footnotetext{
${ }^{18} \mathrm{Abu}$ al-Walīd Muḥammad ibn Aḥmad ibn Muḥammad ibn Aḥmad ibn Rusyd al-Qurṭubī, Bidāyah al-Mujtahid Wa Nihāyah al-Muqtașid, Jilid 3 (t.Cet; Kairo: Dār al-Hadīs̀, 1425 H/2004 M), h. 101.

${ }^{19}$ Talak bain ialah talak yang tidak bisa dirujuk secara langsung. Terbagi atas dua: Pertama, talak bain kecil yaitu perempuan yang telah habis masa idah talak raj'i-nya, sehingga suami (yang telah menalaknya) jika ingin merujuknya harus dengan akad dan mahar baru. Kedua, talak bain besar yaitu perempuan telah ditalak tiga oleh suaminya, dan jika suami ingin merujuknya kembali, maka dia harus menunggu sampai perempuan itu menikah lagi dengan laki-laki lain dengan pernikahan sah dan tidak direkayasa, kemudian dia ditalak lagi sampai habis masa idahnya.

${ }^{20}$ Kementerian Agama Republik Indonesia, Al-Qur'an dan Terjemahnya, h. 424.

${ }^{21}$ Abū Mālik Kamāl ibn al-Sayyid Sālim, Șaḥịh Fiqh al-Sunnah Wa Adillatuhu Wa Tauḍ̄ḥ Maz̄āhib al-Aimmah, Jilid 3, h. 250.

${ }^{22}$ Abū Mālik Kamāl ibn al-Sayyid Sālim, Saḥīh Fiqh al-Sunnah Wa Adillatuhu Wa Tauḍ̄h Maz̄āhib al-Aimmah, Jilid 3, h. 251.
} 
salah satu istrinya dan menyifatinya dengan sifat tertentu (yang identik dengannya) dan tanpa niatan pada selainnya, maka ulama sepakat akan jatuhnya sebuah talak terhadapnya. Begitu pula jika dia menyifatinya dengan sifat yang identik dengan istri yang akan ditalaknya tanpa memberikan isyarat dan tanpa niatan kepada selainnya, misalnya ia mengatakan, "Salma tertalak!". Sementara jika dia mengatakan, "Salah satu istriku tertalak!". Sementara jika dia mengatakan, "Salah satu istriku tertalak!" dengan niat menjatuhkannya pada salah seorang istrinya tanpa menunjuk yang mana, maka istri yang dimaksudkannya saja yang tertalak, bukan yang lain ${ }^{23}$.

Adapun syarat-syarat yang berkaitan dengan metode talak, secara singkat dapat dikatakan bahwa talak bisa terjadi dan sah jika dijatuhkan dengan segala sarana yang bermaksud menghentikan hubungan suami-istri, baik dilakukan dengan ucapan, tulisan, isyarat maupun dengan mengutus orang (delegasi).

\section{1) Talak dengan ucapan}

Adapun ungkapan talak terbagi dua, dengan ucapan dan dengan isyarat. Selain itu, lafaz talak bisa berbentuk lugas atau kiasan. Berikut ini penggambaran lafaz talak dalam bentuk kata-kata lugas maupun kiasan:

\section{a) Kata-kata lugas}

Ucapan yang digunakan untuk menjatuhkan talak, adakalanya diucapkan dengan jelas dan maknanya dapat dipahami serta tidak memiliki pengertian lain, baik dari segi bahasa maupun tradisi. Misalnya ungkapan: "Kamu tertalak!” (anti țāliq), "Aku menceraikanmu!" (tallaqtuki), "Kamu tertalak!" (anti muțallaqah), dan sejenisnya ${ }^{24}$. Jika seorang menalak istrinya dengan ungkapan lugas, maka talaknya dianggap sah walau dia berniat yang lain atau menyangkal ungkapan talaknya tersebut. Hal ini karena maksud dan makna dari ungkapan yang lugas sudah jelas dan ditujukan kepada istri. Kecuali ada indikasi atau kondisi yang mempengaruhi sehingga talak dianggap tidak sah, misalnya orang yang dipaksa atau salah ucap dan lain semacamnya ${ }^{25}$.

Imam Syafi'i berkata, "Di dalam Al-Qur'an ada tiga bentuk ucapan talak yang diucapkan dengan jelas, yaitu al-țalāq (talak/cerai), al-firāq (pisah), al-tasrīh (lepas)."26 Sebagian ulama dari mazhab Ahlu al-Zāhir mengatakan, "Talak tidak sah jika tidak menggunakan tiga kata tadi karena hal itulah yang diterapkan oleh agama. Adapun penggunaan ketiga kata itu adalah ibadah, dengan syarat bahwa ketiga kata itu diucapkan. Oleh karena itu, wajib bagi orang muslim untuk mencukupkan penggunaan lafaz talak

\footnotetext{
${ }^{23}$ Abū Mālik Kamāl ibn al-Sayyid Sālim, Șaḥ̄h Fiqh al-Sunnah Wa Adillatuhu Wa Tauḍ̄ḥ Maz̄āhib al-Aimmah, Jilid 3, h. 251.

${ }^{24}$ Abū Mālik Kamāl ibn al-Sayyid Sālim, Șậ̄ḥ Fiqh al-Sunnah Wa Adillatuhu Wa Taud̄ịh Maz̄āhib al-Aimmah, Jilid 3, h. 251. Lihat juga: Sayyid Sābiq, Fiqh al-Sunnah, Jilid 2, h. 253.

${ }^{25}$ Abū Mālik Kamāl ibn al-Sayyid Sālim, Șaḥịh Fiqh al-Sunnah Wa Adillatuhu Wa Tauḍ̄ḥ Maz̄āhib al-Aimmah, Jilid 3, h. 252-253. Lihat juga: Sayyid Sābiq, Fiqh al-Sunnah, Jilid 2, h. 254.

${ }^{26}$ Muhạmmad ibn Idrīs al-Syāfi' '̄̄, al-Umm, Jilid 5 (t. Cet.: Beirut; Dār al-Ma'rifah, 1410 H/1990 M), h. 276.
} 


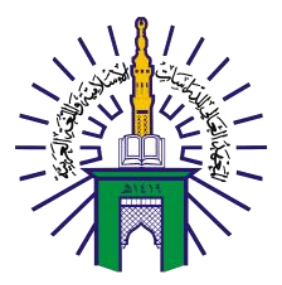

\section{BUSTANUL FUQAHA: \\ JURNAL BIDANG HUKUM ISLAM \\ Vol. 2 No. 2 (2021): Hal. 348-362 \\ EISSN: 2723-6021 \\ Website: https://journal.stiba.ac.id}

kepada lafaz talak yang ada dalam agama." 27 Ungkapan talak telah digunakan dalam AlQur'an, antara lain Qs. al-Țalāq/65:1,

Terjemahnya:

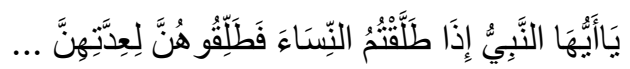

Wahai Nabi! Apabila kamu menceraikan istri-istrimu maka hendaklah kamu ceraikan mereka pada waktu mereka dapat (menghadapi) idahnya (yang wajar) ${ }^{28}$.

2 ,

Terjemahnya:

Sedangkan ungkapan al-firāq digunakan dalam Al-Qur'an, misalnya Qs. al-Ṭalāq/65:

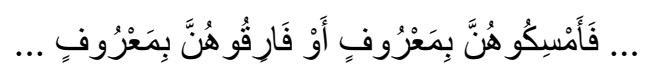

Maka rujuklah mereka dengan baik atau lepaskanlah mereka dengan baik ${ }^{29}$.

Sedangkan ungkapan al-tasrīh atau al-sarāh digunakan dalam Al-Qur'an, antara lain Qs. al-Baqarah/2:229,

Terjemahnya:

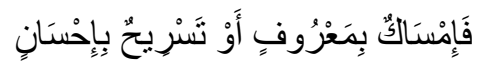

Maka menahan dengan baik atau melepaskan dengan baik ${ }^{30}$.

Dan juga firman Allah swt. dalam Qs. al-Aḥzāb/33:28,

Terjemahnya:

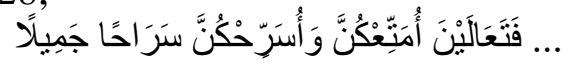

Maka kemarilah agar aku berikan kepadamu mutah dan aku ceraikan kamu dengan cara yang baik ${ }^{31}$.

Berbeda dengan pendapat di atas, mazhab Maliki dan Hanafi berpendapat bahwa lafaz firāq dan tasrīh atau sarāh bukanlah ungkapan lugas untuk menyebutkan perceraian, melainkan merupakan ungkapan kiasan karena bisa berarti perceraian atau lainnya. Sebagaimana dalam firman Allah swt. dalam Qs. Āli 'Imran/3:103,

Terjemahnya:

$$
\text { وَاعْنَهِمُو ا بِحَبْلِ اللَّهِ جَمِيعًا وَلَا تَفَرَّقُو }
$$

Dan berpeganglah kamu semuanya pada tali (agama) Allah swt., dan janganlah kamu bercerai-berai ${ }^{32}$.

Juga pada Qs. al-Bayyinah/98:4,

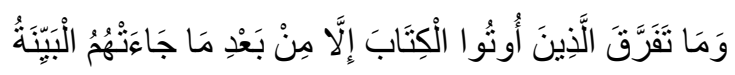

Terjemahnya:

${ }^{27}$ Abu al-Walīd Muḥammad ibn Aḥmad ibn Muḥammad ibn Aḥmad ibn Rusyd al-Qurṭubī, Bidāyah al-Mujtahid Wa Nihāyah al-Muqtașid, Jilid 3, h. 95.

${ }^{28}$ Kementerian Agama Republik Indonesia, Al-Qur'an dan Terjemahnya, h. 558.

${ }^{29}$ Kementerian Agama Republik Indonesia, Al-Qur'an dan Terjemahnya, h. 558.

${ }^{30}$ Kementerian Agama Republik Indonesia, Al-Qur'an dan Terjemahnya, h. 36.

${ }^{31}$ Kementerian Agama Republik Indonesia, Al-Qur'an dan Terjemahnya, h. 421.

${ }^{32}$ Kementerian Agama Republik Indonesia, Al-Qur'an dan Terjemahnya, h. 63. 


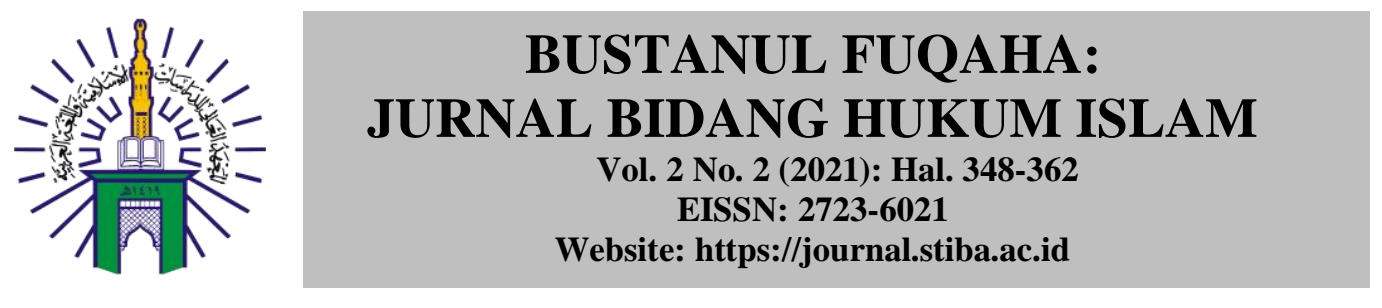

Dan tidaklah berpecah belah orang-orang ahli kitab melainkan setelah datang kepada mereka bukti yang nyata ${ }^{33}$.

Sebagaimana kata firāq (dan derivasinya) dalam kedua ayat di atas tidak ada hubungannya dengan perceraian. Begitu juga dengan firman Allah swt. dalam Qs. alAhzāb/33:49,

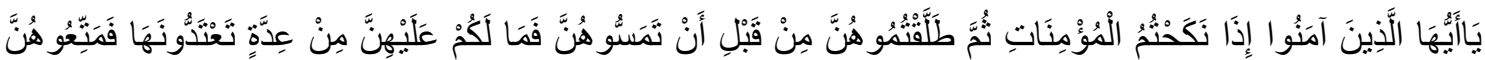

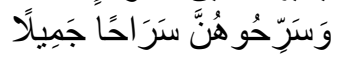

Terjemahnya:

Wahai orang-orang yang beriman, apabila kamu menikahi perempuan-perempuan yang beriman, kemudian kamu menceraikan mereka sebelum kamu mencampurinya maka tidak ada masa idah atas mereka yang perlu kamu perhitungkan. Namun, berilah mereka mutah dan lepaskanlah mereka itu dengan cara yang sebaik-baiknya ${ }^{34}$.

Di sini Allah menyebut kata sarāh setelah memaparkan perceraian. Jika memang demikian, maka lafaz firāq dan sarāh merupakan kiasan. Namun, perlu diketahui bahwa penilaian lafaz talak antara lugas dan kiasan, meskipun merupakan penilaian yang valid dari segi posisi, namun hal ini bisa berbeda-beda menurut pandangan orang, tempat dan waktu, dan bukan paten pada lafaz itu sendiri. Adapun pada kenyataannya dari segi penggunaan, hampir tidak ada seorang pun yang menggunakan lafaz ini untuk menalak istrinya, sedangkan dari segi syarak, terkadang kata itu digunakan untuk makna selain talak $^{35}$.

\section{b) Kata-kata kiasan}

Adalah ungkapan yang sebenarnya tidak digunakan untuk menyebut talak secara khusus, tetapi mengandung arti talak dan lainnya. Jika tidak mengandung unsur talak sama sekali, maka ia bukanlah kiasan, melainkan hanya ungkapan sia-sia yang tidak berimplikasi apa-apa ${ }^{36}$. Contoh ungkapan kiasan adalah jika suami mengatakan kepada istrinya, "Aku lepaskan kamu!" atau, "Segala urusanmu, ada pada dirimu!" atau, "Pulanglah kepada keluargamu" atau, "Kamu haram bagiku" dan semacamnya. Untuk keabsahan talak yang menggunakan ungkapan kiasan dibutuhkan niat (atau kesengajaan untuk menalak), sebab lafaz kiasan mengandung arti talak dan selainnya, sehingga ia tidak bisa diarahkan kepada arti talak kecuali dengan niat demikian. Dengan demikian, jika suami mengucapkan talak dengan ungkapan majas, kemudian menyangkal bahwa ucapannya bukan bermaksud untuk menalak, maka talaknya tidak sah. Hal itu karena

\footnotetext{
${ }^{33}$ Kementerian Agama Republik Indonesia, Al-Qur'an dan Terjemahnya, h. 598.

${ }^{34}$ Kementerian Agama Republik Indonesia, Al-Qur'an dan Terjemahnya, h. 424.

${ }^{35}$ Abū Mālik Kamāl ibn al-Sayyid Sālim, Șaḥịh Fiqh al-Sunnah Wa Adillatuhu Wa Taud̄̄h Maz̄āhib al-Aimmah, Jilid 3, h. 252.

${ }^{36}$ Muḥammad Abdullah ibn Aḥmad ibn Muḥammad ibn Qudāmah al-Maqdisī, al-Mugnī, Jilid 7, h. 391-392.
} 


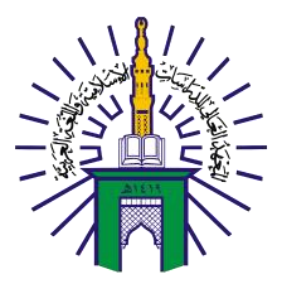

\section{BUSTANUL FUQAHA: \\ JURNAL BIDANG HUKUM ISLAM \\ Vol. 2 No. 2 (2021): Hal. 348-362 \\ EISSN: 2723-6021 \\ Website: https://journal.stiba.ac.id}

ucapannya mengandung makna talak dan selain talak, sedangkan dibutuhkan niat dan tujuan untuk menilai ungkapan majas berpengaruh pada sahnya talak atau tidak ${ }^{37}$.

\section{2) Talak dengan isyarat}

Barangsiapa yang mampu berbicara, maka menurut jumhur ulama (minus kalangan mazhab Maliki) dia tidak dibenarkan menalak dengan isyarat. Adapun orang bisu, maka jumhur ulama menganggap sah talaknya dengan isyarat. Sedangkan kalangan mazhab Syafi'i dan Hanafi menyatakan, talak dengan isyarat tidak disahkan bagi orang bisu yang bisa menulis, sebab tulisan lebih mampu menunjukkan tujuan yang dimaksud, kecuali jika memang kondisinya tidak bisa menulis ${ }^{38}$.

\section{3) Talak menggunakan delegasi (perutusan)}

Talak dianggap sah dan boleh dijatuhkan dengan delegasi (mengutus orang) untuk menyampaikan kepada istri bahwa suaminya telah menalaknya. Adapun utusan (delegasi) tersebut bertindak sebagai suami yang menjatuhkan talak, karena itu talaknya $\operatorname{sah}^{39}$.

\section{Aturan Talak dalam Undang-Undang Nomor 1 Tahun 1974}

Istilah talak atau perceraian terdapat dalam Undang-Undang Nomor 1 Tahun 1974 pasal 38 yang memuat ketentuan fakultatif bahwa, "Perkawinan dapat putus karena: 1) kematian; 2) perceraian; 3 ) atas putusan pengadilan ${ }^{40}$. Putusnya perkawinan dalam hal ini berarti berakhirnya hubungan suami istri. Kematian sebagai salah satu sebab putusnya perkawinan adalah jika salah satu pihak baik suami atau istri meninggal dunia. Adapun putusnya perkawinan dengan perceraian karena talak atau berdasarkan gugatan perceraian, dan putusnya perkawinan dengan keputusan pengadilan adalah jika kepergian salah satu pihak tanpa kabar berita untuk waktu yang lama. Putusnya perkawinan ada dalam beberapa bentuk tergantung dari segi siapa sebenarnya yang berkehendak untuk putusnya perkawinan itu. Dalam hal ini ada 4 (empat) kemungkinan: ${ }^{41}$ 1) Putusnya perkawinan atas kehendak Allah swt. sendiri melalui matinya salah seorang suami atau istri yang disebut dengan cerai mati; 2) Putusnya perkawinan atas kehendak suami dengan alasan tertentu disebut talak; 3) Putusnya perkawinan atas kehendak dan permintaan dari istri disebut khuluk; 4) Putusnya perkawinan atas kehendak hakim sebagai pihak ketiga setelah melihat adanya sesuatu pada suami dan atau pada istri yang menandakan tidak dapatnya hubungan perkawinan itu dilanjutkan. Putusnya perkawinan dalam bentuk ini disebut fasakh.

\footnotetext{
${ }^{37}$ Abū Mālik Kamāl ibn al-Sayyid Sālim, Șaḥ̄ḥ Fiqh al-Sunnah Wa Adillatuhu Wa Taud̄ịh Mazāhib al-Aimmah, Jilid 3, h. 253-254. Lihat Juga: Sayyid Sābiq, Fiqh al-Sunnah, Jilid 2, h. 254.

${ }^{38}$ Abū Mālik Kamāl ibn al-Sayyid Sālim, Șaḥ̄h Fiqh al-Sunnah Wa Adillatuhu Wa Taudīh Maz̄āhib al-Aimmah, Jilid 3, h. 259.

${ }^{39}$ Sayyid Sābiq, Fiqh al-Sunnah, Jilid 2, h. 257.

${ }^{40}$ Republik Indonesia, Undang-undang Nomor 1 Tahun 1974 Tentang Perkawinan, bab VIII, pasal 38.

${ }^{41}$ Hasyim Fahmi, "Keabsahan Talak dalam Perspektif Hukum Positif dan Fiqih Munakahat (Konflik Norma)", Skripsi (Malang: Fak. Syariah Universitas Islam Negeri Maulana Malik Ibrahim Malang, 2017), h. 21-22.
} 


\section{Syarat-Syarat Talak dalam Undang-Undang Nomor 1 Tahun 1974}

Menurut Undang-Undang Nomor 1 Tahun 1974, suami atau istri yang ingin mengajukan gugatan perceraian harus memenuhi syarat-syarat sah cerai sebagaimana yang diuraikan pada Pasal $39^{42}$, yaitu perceraian hanya dapat dilakukan di depan sidang pengadilan setelah pengadilan yang bersangkutan berusaha dan tidak berhenti mendamaikan kedua belah pihak, karena perceraian hanya bisa dilakukan setelah terbukti bahwa antara suami istri tersebut tidak akan dapat hidup rukun sebagai suami istri. Adapun tata cara perceraian diatur dalam peraturan pemerintah Republik Indonesia Nomor 9 Tahun 1975 pasal 14 sampai dengan $18^{43}$. Pada pasal 14 disebutkan bahwa seorang suami yang telah melangsungkan perkawinan menurut agama Islam, yang akan menceraikan istrinya, mengajukan permohonan cerai kepada pengadilan di tempat tinggalnya, yang berisi maksud menceraikan istrinya disertai dengan alasan-alasannya serta meminta kepada pengadilan agar diadakan sidang untuk keperluan itu.

Pada pasal 15 disebutkan bahwa pengadilan yang bersangkutan mempelajari isi surat permohonan cerai yang dimaksud dalam pasal 14, dan dalam waktu selambat-lambatnya 30 (tiga puluh) hari memanggil pemohon dan istrinya untuk meminta penjelasan. Pada paasal 16 disebutkan bahwa pengadilan hanya memutuskan untuk mengadakan sidang pengadilan untuk menyaksikan perceraian yang dimaksud dalam pasal 14 apabila memang terdapat alasan-alasan seperti yang dimaksud dalam pasal 19 dan pengadilan berpendapat bahwa antara suami istri yang bersangkutan tidak mungkin lagi didamaikan untuk hidup rukun dalam rumah tangga. Pada pasal 17 disebutkan bahwa sesaat setelah dilakukan sidang perceraian yang dimaksud dalam pasal 16, ketua pengadilan membuat surat keterangan tentang terjadinya perceraian tersebut. Surat keterangan tersebut dikirimkan kepada pegawai pencatat di tempat perceraian itu terjadi untuk diadakan pencatatan perceraian.

\section{Komparasi Keabsahan Talak dalam Tinjauan Fikih Islam Terhadap Undang- Undang Nomor 1 tahun 1974}

Talak dalam fikih Islam dianggap sah ketika memenuhi syarat-syarat sah talak yaitu, suami yang sah sebagai penjatuh talak, dengan kriteria telah balig dan berakal, serta menjatuhkan talaknya atas kehendaknya sendiri tanpa ada paksaan dari orang lain, dan hendaknya Istri yang ditalak adalah istri yang sah, dan suami menjatuhkan talak atasnya dengan menentukannya dengan isyarat, atau dengan menyifatinya, atau dengan niat, atau dengan ketiga-tiganya, dengan menggunakan ungkapan, baik ungkapan yang jelas (lugas) ataupun ungkapan kiasan yang disertai dengan niat menalak. Suami juga bisa menalak istrinya dengan tulisan yang disertai dengan niat menalak. Bagi suami yang bisu dan tidak bisa menulis, maka diperbolehkan untuk menalak dengan isyarat.

Dalam fikih Islam, suami dapat menalak istrinya kapanpun dan di manapun, dan dianggap sah ketika memenuhi syarat-syarat sah di atas. Berkenaan status perceraian yang tidak dilakukan di depan pengadilan agama atau di depan hakim, maka talaknya tetap

${ }^{42}$ Republik Indonesia, Undang-Undang Nomor 1 Tahun 1974 Tentang Perkawinan, bab VIII, pasal

${ }^{43}$ Republik Indonesia, Peraturan Pemerintah Nomor 9 tahun 1975 Tentang Pelaksanaan UndangUndang Nomor 1 Tahun 1974 Tentang Perkawinan, bab V, pasal 14-18. 


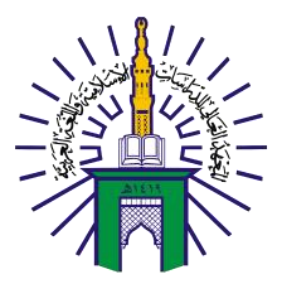

\section{BUSTANUL FUQAHA: \\ JURNAL BIDANG HUKUM ISLAM \\ Vol. 2 No. 2 (2021): Hal. 348-362 \\ EISSN: 2723-6021 \\ Website: https://journal.stiba.ac.id}

dianggap sah karena dalam literatur Islam tidak diharuskan perceraian dilakukan di depan pengadilan.

Talak suami kepada istrinya dengan ucapan yang jelas, maka dianggap sah terlepas dari apakah dia meniatkannya atau tidak, apakah dia bersunguh-sungguh atau tidak. Sebagaimana hadis Nabi saw. yang masyhur yang diriwayatkan oleh sahabat yang mulia Abu Hurairah ra.,

Artinya:

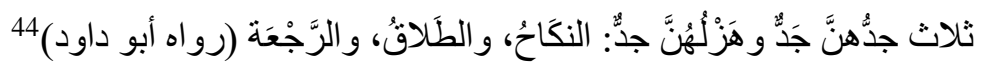

Tiga perkara, seriusnya dianggap serius, dan gurauannya dianggap serius, yaitu nikah, talak, dan rujuk (H.R. Abū Dāwūd).

Sedangkan ketika suami menalak istrinya dengan ungkapan kiasan, tulisan, isyarat, ataupun dengan delegasi, maka untuk keabsahannya dipersyaratkan harus diiringi dengan niat karena cara menjatuhkan talak yang mengandung makna selain talak. Adapun peraturan talak perspektif Undang-Undang Perkawinan Nomor 1 Tahun 1974, Peraturan Pemerintah Nomor 9 Tahun 1975 dan Kompilasi Hukum Islam mensyaratkan talak harus diajukan di persidangan pengadilan agama dan berdasarkan pasal 17 Peraturan Pemerintah Nomor 9 Tahun 1975 yang pada intinya Ketua Pengadilan membuat surat keterangan tentang terjadinya perceraian tersebut, surat keterangan yang dimaksud adalah dalam bentuk akta cerai yang dikuatkan oleh putusan pengadilan. Surat keterangan/akta cerai tersebut secara hukum sebagai bukti surat bahwa antara suami dan istri sah bercerai karena talak dengan demikian keduanya sudah tidak lagi ada hubungan hukum sebagai suami istri.

Peraturan Pemerintah Nomor 9 Tahun 1975, berupaya untuk membentuk ketahanan keluarga, dengan melakukan mediasi untuk mendamaikan pasangan suami istri yang hendak melakukan perceraian, hal ini sesuai dengan tuntutan syariat Islam, sebagaimana dalam firman Allah swt. dalam Qs. al-Nisa/4: 35,

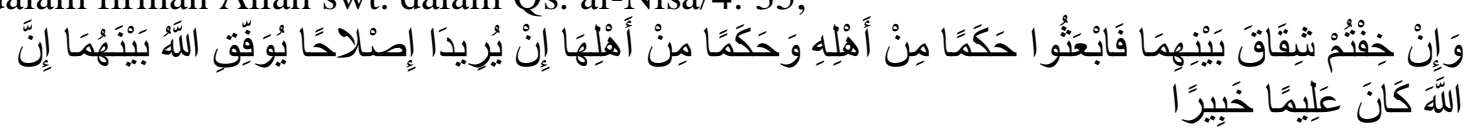

Terjemahnya:

Dan jika kamu khawatir terjadi persengketaan antara keduanya, maka kirimlah seorang juru damai dari keluarga laki-laki dan seorang juru damai dari keluarga perempuan. Jika keduanya (juru damai itu) bermaksud mengadakan perbaikan, niscaya Allah memberi taufik kepada suami-istri itu. Sungguh, Allah Maha Teliti, Maha Mengenal ${ }^{45}$.

Dari ayat di atas, terlihat peran pengadilan dapat berfungsi sebagai juru damai antara suami-istri sekaligus menertibkan perceraian dengan melakukan pencatatan, upaya ini dilakukan untuk meminimalisir permasalahan yang terjadi akibat kerusakan akhlak manusia saat ini. Jika pernikahan, talak dan rujuk tidak tercatat, maka sangat mudah bagi istri-istri yang tidak takut kepada Allah swt. untuk mengaku telah diceraikan untuk

\footnotetext{
${ }^{44}$ Abū Dāwud Sulaimān ibn al-Asy’as ibn Isḥāq al-Azdī al-Sijistān̄̄, Sunan Abī Dāwud, Jilid 3 (Cet. I; Lebanon: Dār al-Risālah al-'Āmaliyyah, 1430 H/2009 M), h. 516.

${ }^{45}$ Kementerian Agama Republik Indonesia, Al-Qur'an dan Terjemahnya, h. 85.
} 


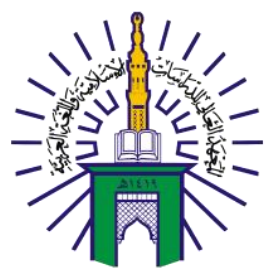

\section{BUSTANUL FUQAHA: \\ JURNAL BIDANG HUKUM ISLAM \\ Vol. 2 No. 2 (2021): Hal. 348-362 \\ EISSN: 2723-6021 \\ Website: https://journal.stiba.ac.id}

menikah padahal statusnya masih istri yang sah bagi suami pertamanya, atau suami mengumpulkan lebih dari empat istri. Adapun hal yang mengharuskan talak di pengadilan, maka ia tidak bertentangan dengan fikih Islam, bahkan ulama telah sepakat tentang disunahkannya keberadaan saksi dalam talak, hal ini dikuatkan oleh ulama kontemporer bernama Abu Bakar Jabir Al-Jazairi ${ }^{46}$. Dengan demikian, ketentuan aturan talak di pengadilan menghendaki atau mengharapkan agar para suami tidak mudah untuk mentalak istrinya. Adapun jika terlanjur menalak istri di luar pengadilan, maka dianjurkan agar si suami melaporkannya ke pengadilan agama.

\section{KESIMPULAN}

Penelitian ini bertujuan untuk mengetahui tinjauan fikih Islam terhadap UndangUndang Nomor 1 Tahun 1974 tentang penetapan aturan yang mewajibkan talak di depan pengadilan Agama. Hasil penelitian ini menunjukkan bahwa meskipun dalam fikih Islam, talak bisa saja terjadi dan dianggap sah, kapanpun dan di manapun, akan tetapi memiliki syarat yang perlu diperhatikan, yakni jika suami yang menjatuhkan talak tersebut telah balig, berakal dan tidak berada dalam tekanan atau paksaan. Namun, Undang-Undang Nomor 1 tahun 1974 mensyaratkan akan sahnya talak, menyatakan bahwa talak diajukan dan dilakukan di depan sidang pengadilan agama. Syarat ini tidak bertentangan dengan fikih Islam bahkan sebagian mazhab berkeyakinan akan wajibnya keberadaan saksi atas talak. Bahkan kehadiran pengadilan dalam urusan talak juga bisa meminimalisir jatuhnya talak, karena pengadilan berupaya untuk mendamaikan pasangan suami istri yang mengajukan talak.

Talak yang dilakukan di depan pengadilan bukan hanya sebagai bentuk legalitas atas pengakuan negara, namun lebih dari itu, bisa menjaga hak-hak suami istri baik dalam hubungan perkawinan maupun setelah putusnya perkawinan. Jika sekiranya seorang suami telah mentalak istrinya di luar pengadilan, maka ia hendaknya melaporkannya dan berupaya mencatatkannya di pengadilan agama, agar tegak syariat Allah swt.

\section{DAFTAR PUSTAKA}

Al-Jauzajān̄i, Sa'̄̄d ibn Manșūr al-Khurasānī. Sunan Sa'ìd ibn Manșūr. Jilid 1. Cet. I; India: al-Dār al-Salafiyyah, 1982.

Al-Maqdis̄̄, Abu Muḥammad Abdullah ibn Aḥmad ibn Muḥammad ibn Qudāmah. alMugnī, Jilid 7. t.Cet.; Kairo: Maktabah Kairo. 1968.

Al-Naisābūrī, Muslim bin al-Hajjāj al-Qusyairī. Ṣaḥịh Muslim. Jilid 4. t.Cet.; Beirut: Dār Iḥyā' al-Turāì al-'Arabī. 1954.

Al-Qurțub̄ê, Abu al-Walīd Muḥammad ibn Aḥmad ibn Muḥammad ibn Aḥmad ibn Rusyd. Bidāyah al-Mujtahid Wa Nihāyah al-Muqtașid. Jilid 3. t.Cet; Kairo: Dār al-Hadīì. 2004.

Al-Sijistānī, Abu Dāud Sulaimān ibn al-Asy’as ibn Isḥāq al-Azdī. Sunan Abī Dāwud, Jilid 3. Cet. I; Lebanon: Dār al-Risālah al-'Āmaliyyah. 2009.

Al-Syāfi' '̄, Muḥammad ibn Idrīs. al-Umm, Jilid 5. t. Cet.: Beirut; Dār al-Ma’rifah. 1990.

${ }^{46}$ Soraya Devy dan Luthfia Mawaddah, "Kesaksian dalam Talak Menurut Abu Bakar Jabir AlJazairi,” (El-Usrah: Jurnal Hukum Keluarga) 1, no. 1 (Januari-Juni 2018), h. 62 


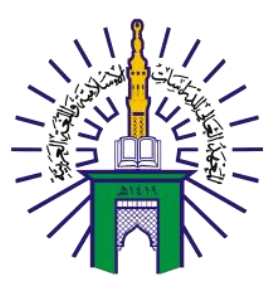

\section{BUSTANUL FUQAHA: \\ JURNAL BIDANG HUKUM ISLAM \\ Vol. 2 No. 2 (2021): Hal. 348-362 \\ EISSN: 2723-6021 \\ Website: https://journal.stiba.ac.id}

Databoks. "Indonesia, Negara dengan Penduduk Muslim Terbesar Dunia", Situs Resmi Databoks. http://databoks.katadta.co.id/datapublish/2019/09/25/indonesianegara-dengan-penduduk-muslim-terbesar-dunia.

Devy, Soraya, and Luthfia Mawaddah. "Kesaksian dalam Talak Menurut Abu Bakar Jabir AlJazairi." El-USRAH: Jurnal Hukum Keluarga 1.1 (2018): 57-73.

Fahmi, Hasyim."Keabsahan Talak dalam Perspektif Hukum Positif dan Fiqih Munakahat (Konflik Norma)". Skripsi. Malang: Fak. Syariah Universitas Islam Negeri Maulana Malik Ibrahim Malang. 2017.

Hikmatullah, Hikmatullah. "Selayang Pandang Sejarah Penyusunan Kompilasi Hukum Islam Di Indonesia." Ajudikasi: Jurnal Ilmu Hukum 1.2 (2017).

Ibn Taimiyah, Aḥmad ibn 'Abdul Ḥalīm. Majmū' al-Fatāwā. Jilid. 33. t. Cet.: Madinah; Mujamma' al-Malik Fahd Li Ṭabā'ah al-Muṣ̣haf al-Syarīf. 2004.

Kementerian Agama Republik Indonesia. Al-Qur'an dan Terjemahnya. Cet. I; Jakarta: Ummul Qura, 2017.

Laila, Aila. Analisis Terhadap Perceraian Melalui SMS Pada Kasus Aceng Fikri (Bupati Garut) Menurut Undang-Undang Nomor 1 Tahun 1974 Tentang Perkawinan/oleh Aila Laila. Diss. UNIVERSITAS TARUMANEGARA, 2013.

Rahmat, Rahmat, and Sri Indriani. "Hukum Idah Perceraian bagi Wanita Hamil Akibat Perbuatan Zina." BUSTANUL FUQAHA: Jurnal Bidang Hukum Islam 1.4 (2020): 588-610.

Redaksi Visimedia. Undang-Undang Dasar 1945. Cet. III; Jakarta: Visimedia, 2007.

Republik Indonesia, Peraturan Pemerintah Nomor 9 tahun 1975 Tentang Pelaksanaan Undang-Undang Nomor 1 Tahun 1974 Tentang Perkawinan.

Republik Indonesia, Undang-undang Nomor 1 Tahun 1974 Tentang Perkawinan.

Sabiq, Sayyid. "Fiqh al-Sunnah, jilid II." Beirut: Dar al-Fikr (1983).

Sālim, Abū Mālik Kamāl ibn al-Sayyid. Șaḥ̄ḥ Fiqh Al-Sunnah Wa Adillatuhu Wa Taud̄ịh Mazāhib al-Aimmah. Jilid 3., Cet. I; Kairo: al-Maktabah al-Taufīqiyyah. 2003. 